\title{
28 Research Soure \\ Clarifying the mechanism of EGFR inhibition in KRAS G13D colorectal cancer
}

Thomas McFall

Noah K. Schomburg

Kent L. Rossman

Edward C. Stites

\section{Video Byte}

Keywords: Cell Communication and Signaling, KRAS, GTPase, EGFR, Cancer, Targeted Therapy, colorectal cancer, RAS signaling pathways, HRAS, NRAS, NF1, KRAS G13D mutation

Posted Date: November 13th, 2020

DOl: https://doi.org/10.21203/rs.3.rs-107498/v1

License: @ (i) This work is licensed under a Creative Commons Attribution 4.0 International License.

Read Full License 


\section{Abstract}

Overexpression of the protein EGFR is associated with various cancers. That's made EGFR inhibitors a promising class of anti-cancer drugs. Although EGFR targeting of colorectal cancer is well understood, some patients respond unexpectedly well. A pair of studies have studied why cancers with the KRAS G13D mutation respond well to EGFR inhibition. They propose different mechanisms to explain the beneficial response. One study suggests that a tumor-suppressing protein known as NF1 decreases the KRAS activity that drives cancer growth. The other suggests that NF1 actually decreases NRAS and HRAS but not KRAS. Now, a new study appears to provide some clarity in the matter. Using antibodies specific to each RAS protein, researchers showed that an abundance of NF1 downregulates the proteins NRAS and HRAS in colorectal cancer cells, with no effect on KRAS. The idea that KRAS was the key may have been a misinterpretation of previous experiments, which used an antibody kit that could track RAS proteins in general but not KRAS specifically. More studies are needed to clarify how other mutations in the KRAS protein affect patients' sensitivity to EGFR inhibitors and how EGFR inhibitors can be made more effective against cancer. 